\title{
Satranç: Doğu Medeniyetinin Batı'ya Bir Hediyesi
}

Ayşe Beyza ERCAN ${ }^{1}$

$\ddot{O} \mathbf{z}$

İnsanlığın kültürel ve sosyal tarihinde küçük bir bölüm olan satrancın köken tartışmaları güncelliğini korumaya devam etmektedir. Satranç kimine göre bir entelektüel spor dalı, kimine göre evde oynanan basit bir oyun, kimine göre bir strateji oyunu, kimine göre ise zekâ geliştirici bir egzersiz türüdür. Chaturanga olarak adlandırılan ve tüm dünyaya yayılan satranç 6 . yüzyılda Hindistan'da ortaya çıkan ve kendisinden en çok bahsettiren oyunlardan sadece bir tanesidir. Orta Çağ döneminde halk kadar hükümdarların da sıklıkla bu oyunu oynadığı kaynaklarda sabittir. $\mathrm{Bu}$ nedenle bu oyun nitelik olarak bir strateji oyunu olduğundan Orta Çağ döneminde ve daha sonrasında da hükümdarların savaşa hazırlık için yapmış oldukları bir taktik geliştirme egzersizi olarak görülmüştür. $\mathrm{Bu}$ makalede geniş bir coğrafya ele alınarak köklü geçmişe sahip olan satrancın Orta Çağ Türk-İslâm dünyasındaki önemi ve yayılma güzergâhı ile yeni tanıştı̆̆ı Avrupa dünyasındaki rolüne değinilecektir.
Anahtar Sözcükler

İran

İspanya

Orta Çăg Avrupa’sı

satranç

satranç taşları

Türk-İslâm medeniyeti

Makale Hakkında

Geliş Tarihi: 30.04.2021

Kabul Tarihi: 16.06.2021

Doi:

10.20304/humanitas.930192

\section{Chess: A Gift from the Orient to the West}

\begin{abstract}
Debates on the origin of chess, a small part of the cultural and social history of mankind, remain up-to-date. Many see chess as a simple game played at home but for some, chess is also a mind sport, a strategy game, or a way for mind exercise. Originally known as chaturanga, chess is only one of many globally embraced games that were originated in India. There is enough evidence in the sources that the monarchical rulers, as well as ordinary people, played chess in the Middle Ages. Chess was seen as an act of preparatory exercise by the rulers in preparation for war in the Middle Ages. This article focuses on the importance of chess in the Turkic-Islamic world and its route in its dissemination in the medieval period, as well as its role in Europe.
\end{abstract}

\author{
Keywords \\ Iran \\ Spain \\ Medieval Europe \\ chess \\ chess pieces
}

Turkish-Islamic civilization

About Article

Received: 30.04 .2021

Accepted: 16.06.2021

Doi:

10.20304/humanitas.930192

\footnotetext{
1 Dr. Öğr. Üyesi, Ardahan Üniversitesi, Ardahan İnsani Bilimler ve Edebiyat Fakültesi, Tarih Bölümü,
} Ardahan/Türkiye, aysebeyzaercan@ ardahan.edu.tr, ORCID: 0000-0003-0464-2716 


\section{Giriş}

"Hataların hepsi yapılmayı bekliyor."

Savielly Tartakower ${ }^{1}$

Çeşitli değişimler ve oyun eklemeleriyle günümüze ulaşmış olan, tüm dünyada popülerliğini koruyan, aynı zamanda da entelektüel bir spor dalı olarak bilinen satranç, iki kişi tarafından karşılıklı olarak oynanan bir masa oyunudur. Dünya tarihinde hiçbir oyun satranç kadar önemli bir konuma sahip olamadığı gibi, onun kadar geçmişten günümüze kozmopolit bir eğlence türü olarak varlığını korumayı başaramamıştır (Macdonell, 1898, s. 117). Satranç kare bir alan üzerinde iki kişi arasında taşların oyun kurallarına uygun bir şekilde sırayla hareket ettirilmesi şeklinde oynanmaktadır. Her iki rakibin amacı, kurallar gereğince doğru bir hamle ile karşı tarafın şahına saldırmaktır. Bunu gerçekleştiren kişi karşı tarafı şah-mat yaparak oyunu kazanır. Rakipler şah-mat yapamazlarsa oyun berabere biter, bu şekilde de pat olur. Bugün altmış dört (sekiz x sekiz) eşit kareden oluşmakta olan satranç tahtasında kareler sırayla açık ve koyu renktedir. Oyunun başındaki her iki rakibin önünde bir şah, bir vezir, ikişer fil, ikişer kale, ikişer at ve son olarak sekiz adet piyon bulunmaktadır (Altınay, 2009, s. 178).

Doğu dünyasının batıya transfer etmiş olduğu bu oyun ile ilgili satranç tarihi denildiğinde akla gelen ilk isimlerden biri olan H. J. R. Murray, kitabının birinci bölümüne başlarken satrancı şu şekilde izah eder:

Tarihsel olarak satranç bir savaş oyunu olarak sınıflandırılmalıdır. İki oyuncu, bir savaş alanında eşit güçte iki ordu arasında, kapsamı sınırlanmış ve her iki tarafa da zemin avantajı sağlamayan bir çatışmayı yönetir. Oyuncular, kendi akıl yürütme yeteneklerinin sağladığı yardımlardan başka bir yardıma sahip değildirler ve zafer genellikle stratejik hayal gücü daha güçlü olana, kuvvetlerinin yönü daha becerikli olana, pozisyonları öngörebilme yeteneği daha gelişmiş olana düşer (Murray, 1913, s. 25).

Satranç tarihi üzerine, Murray ve Richard Eales tarafından yapılan çalışmalar başta olmak üzere birçok farklı bilimsel eser vardır. H. F. Maßmann'ın (1839) kitabı, bunlardan biri olup Maßmann, satrancın Hindistan'da icat edildiğine ve oradan İran ve Araplar vasıtasıyla Batı'ya geldiğine dair kesin bir görüşe sahiptir. Satrancın kökeni hakkındaki bilimsel araştırmanın başlangıcı, Thomas Hyde'ın De Ludis Orientalibus isimli 1694 tarihli bir yayınına dayanmaktadır. Hyde, eski Arap kaynaklarına dayanarak, satrancın Hindistan'da

\footnotetext{
${ }^{1}$ 1887-1957 yılları arasında yaşamış ünlü satranç oyuncusudur. Kendisine atfedilen bu sözün bir diğer versiyonu da "Hataların hepsi tahtada yapılmaya bekliyor" şeklindedir.
} 
ortaya çıktığı ve ardından İran ve Arap dünyasından Batı Avrupa'ya ve İpek yolu üzerinden Doğu'ya ulaştı̆̆ı sonucuna varmıştır (Remus, 2003, s. 8).

Fakat yukarıda anlatılanların yanı sıra az da olsa satrancın doğuşu ve yayılış güzergâhı ile ilgili farklı görüşler de bulunmaktadır. Satrancın Hindistan'dan veyahut Çin'den tüm dünyaya yayıldığı görüşünün aksine Kuşan Türkleri tarafından MS 50-200 yılları arasında bulunduğu fikri de mevcuttur (Josten, 2001, s. 13). Orta Çağ'’n bu popüler oyununun menşe alanı hakkında Josten, Yakın Doğu, Hindistan ve Çin ile yoğun teması olan bir kültür durumundaki Orta Asya Kuşan İmparatorluğu'na işaret etmektedir. Bazı bilim adamları tarafından “Unutulmuş Kuşanlar” olarak adlandırılan Kuşanlar, MÖ 50'den MS 200'e kadar Hindistan'ın önemli bir bölümünü içeren büyük bir imparatorluğu yönetmişlerdir. Bu bölgede MS 2. yüzyıla ait "satranç taşlarının" bulunmasından ötürü Josten, satrancın çıkış noktasının bu bölge olduğunu savunmaktadır.

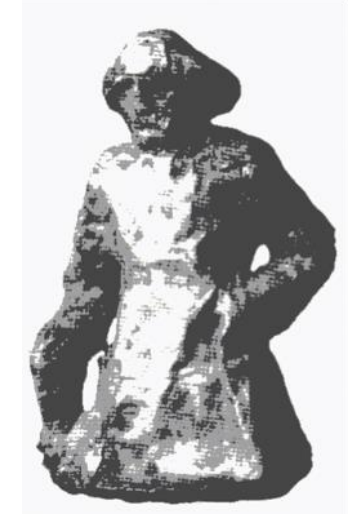

Şekil 1. MS 1- 2. yüzyıla ait Kuşan parçası ${ }^{1}$

Bilimsel literatürün çoğu, satrancın Kuzey Hindistan'da, Avrupa ile Uzak Doğu'yu birbirine bağlayan eski ticaret yollarının çok yakınında, MS 600 civarında ortaya çıktığı konusunda hemfikirdir. Oyun, önümüzdeki birkaç yüz yıl boyunca İranlı tüccarlar ve Kuzey Afrika'da yaşayan Berberi bir halk olan Morolar aracılığıyla Avrupa'ya taşındıkça bugün bildiğimiz şekline dönüşmüştür (Africanus Leo, 1896, s. 108; Pagnotti ve Russell, 2012, s. 30). Ancak öne sürülen bu tezlerin dışında, satrancın ortaya çıkışıyla ilgili bilgileri Hermes'e (İdris Peygamber) kadar dayandıran görüşler de mevcudiyetini korumaktadır. Tüm bunların dışında da satrancın Yunanistan, Rusya, Mısır, İrlanda gibi pek çok ülkeden ve hatta tarihi Mezopotamya bölgesinden çıktığını kabul eden görüşler de vardır. Aynı zamanda daha az kabul gören bir diğer görüşe göre ise satranç İran'da ortaya çıkıp İran üzerinden Hindistan’a ulaşmıştır (Bland, 1852, s. 6; Altınay, 2009, s. 179; Altungök, 2014, s. 471).

1 Bu figürü "parça" olarak isimlendirmemizin sebebi Josten'in tam olarak bu nesneyi satrançla ilişkilendirememesi ancak tezine bir örnek olarak sunmasından ötürüdür (Josten, 2001, s. 14). 
Satranç konusunu çalışan tarihçiler tarafından tartışılan bir diğer husus ise satrancın ismi ve bu ismin değiştirdiği formdur. Sanskritçe'de bu oyuna chaturanga ismi verilmekteydi ve bu isim Hint ordusunun dört kısmına işaret etmekteydi. Chatur Sanskritçe'de dört anlamına gelmekteyken anga ise unsur/kısım anlamlarına gelmektedir (Pankhurst, 1971, s. 149). Bahsi geçen bu dört unsur savaş arabaları, filler, süvariler ve piyadelerdir. MÖ 326'da İskender'in seferi sırasında Punjab Kralı Porus 30.000 piyade, 4.000 süvari, 200 fil ve 300 savaş arabasından oluşan bir orduyla İskender'in ordusuna karşı savaşmıştır (Macdonell, 1898, s. 118). Chaturanga'nın isminin hikâyesi de bu tarihi olaya bağlanmaktadır. Bunun dışında, chaturanga kelimesi Mahābhārata ve Ramayana isimli iki Hint destanında sık sık geçmektedir (Macdonell, 1898, s. 117). Bir müddet sonra, Hindistan’da bu dört kısma kral ve onun generali eklenerek oyunun temel parçaları oluşturulmuş ve bu şekilde tüm dünyaya yayılma serüveni başlamıştır (Yalom, 2005, s. 3). Satranç ile ilgili ilk kayıtlardan anlaşıldığı üzere, Hindistan'da bu oyunun oynandığı tahtaya da aştapada (sekiz-kare) ismi verilmekteydi (Macdonell, 1898, s. 119).

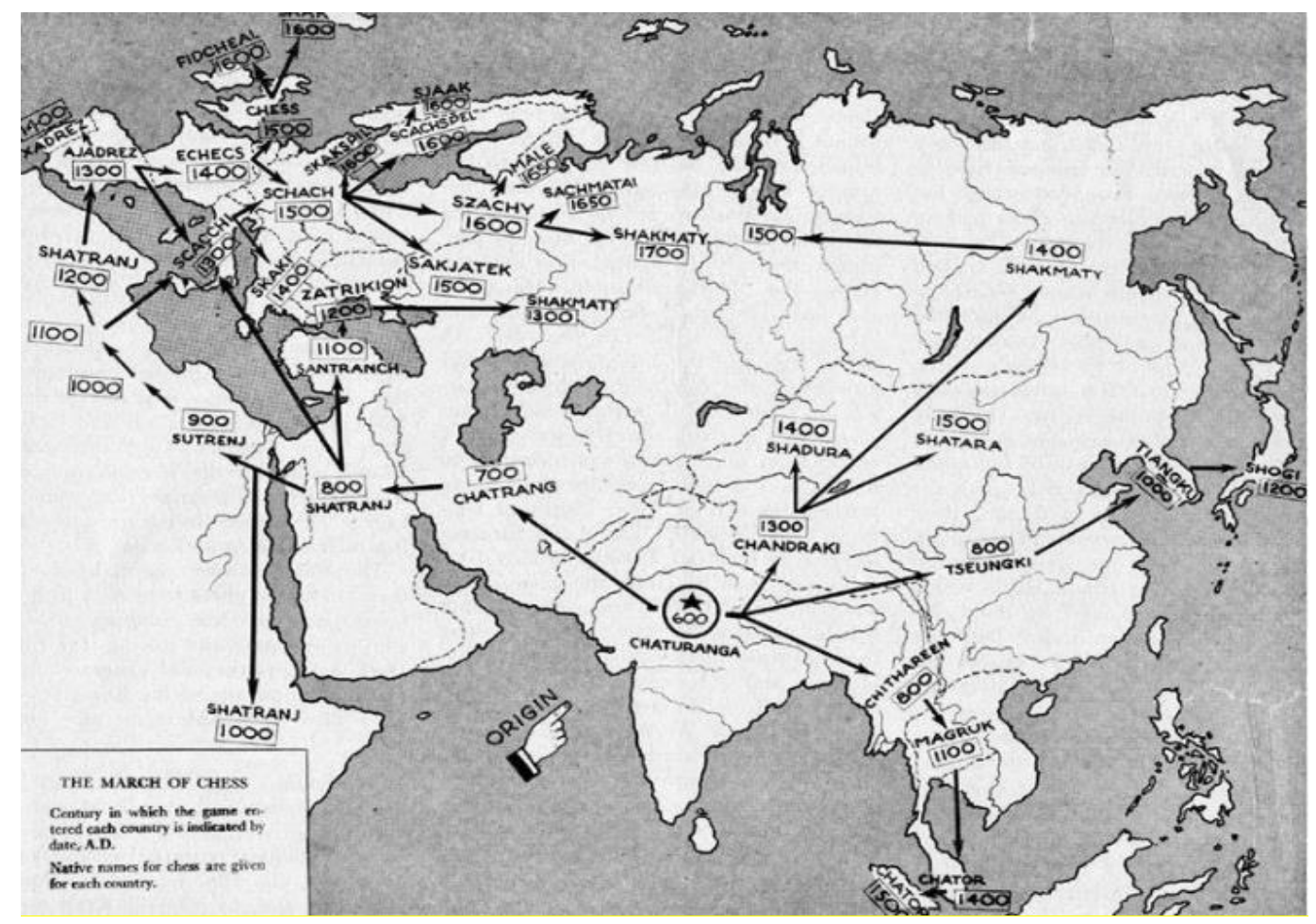

Şekil 2. Satranç kelimesinin dünya üzerinde yayılışı ve isim değişikliklerini gösteren harita (Vivid Maps)

Sanskritçe'de chaturanga olarak bilinen bu oyun dünya üzerinde yolculuk yaptıkça isim olarak da çeşitli formlara dönüşmüştür. Farsça'da çet-reng Arapça'da ise şatranc olarak anılmaya başlanmıştır. Bu kelime ile ilgili farklı görüşlerden bir diğeri de yukarıda anlatılanların aksine Farsça'daki altı renk anlamında olan şeş-reng kelimesinden geldiği 
yönündedir. Bahsi geçen renk veya türden kast edilen ise şah, vezir, fil, at, kale ve piyadeye yani satrancın altı taşına işaret etmesidir. Satranç tahtasında sekiz kare bulunduğundan Farsça'da sekiz renk anlamına gelen heşt-reng sözcügünün bu kelimenin kökeni olduğu da savunulmuştur (Altınay, 2009, s. 178). Ancak, bu görüş literatürde kendisine çok da yer bulamamış gözükmektedir.

\section{Satrancın Hindistan'dan İran'a Yolculuğu}

Hiç şüphesiz ki, İran'ın Araplar tarafından fethedilmesinin ardından satrancın dünyaya yayılma serüveni de başlamıştır (Gizycki, 1972, s. 11). Satranç hediye olarak, Hint hükümdarı tarafından Sâsâni hükümdarı Hüsrev I. Anuşirvan'a gönderilmiştir. Veziri Büzürcmihr (Bozorgmerh) oyunu geliştirerek yeni bir oyun daha ilave etmiştir. Râvendî’ye göre, Anuşirvan da bu oyunu Rum Kayserine (Bizans İmparatoruna) göndermiş, o da satranca iki oyun daha eklemiştir (Râvendi, 2020, s. 376). Böylece, çıkış noktasından ayrılarak dünya üzerinde ilerlemeye başlayan satranç aynı şekilde gelişmeye de başlamıştır.

Satrancın tüm dünyaya yayılma hikâyesinde genellikle üç millet üzerinden bir varsayım türetilmektedir. Bunlar Hintliler, Persliler ve Araplardır. Örneğin, İran satrancın kendi coğrafyasına Hindistan'dan ulaştığını genel olarak kabul etmektedir. Şahnâme'de de adından sıklıkla söz ettiren satranç Firdevsî’ye göre de Hindistan menşelidir (Altınay, 2009, s. 179). Etiyopya’ya ise satrancın Araplar aracılığı ile geldiği öngörülmektedir (Pankhurst, 1971, s. 149). Gürcüler ise, satrancın İran veyahut Hindistan aracılığıyla ülkelerine geldiklerini savunmaktadırlar. Satranç, birçok Gürcü edebi ve tarihi kaynağında da geçmektedir. Gürcistan'da satranç ile ilgili ilk kayıtlar 11. yüzyıl Gürcistan'ının dinî figürü olan George Atoneli tarafından Gürcüce'ye çevrilen "Altı Gün" adlı eserde bahsedilmiştir. Gürcü tarih yazıcılığına göre, satranç Arapların Gürcistan'a gelmesinden önce de ülke sınırları içerisinde bilinmekteydi. Bu sebeple Gürcü tarihçiler satrancın Gürcistan'a Hintli tüccarlar veya Persler tarafından getirilmiş olmasının daha muhtemel olduğunu ileri sürmektedirler. ${ }^{2}$ Gürcü satranç oyuncuları hakkında 19. yüzyıla kadar hiçbir bilgi olmamasına rağmen, 12, 15 ve 17. yüzyıllara ait Gürcü satranç takımlarının varlığı ${ }^{3}$ bu yüzyılların en revaçta oyunu olan satrancın Gürcistan'da tercih edilen bir oyun olduğunu düşündürmektedir.

\footnotetext{
${ }^{2}$ Gürcistan'da 7-11. yüzyıllar arası var olan Arap hâkimiyeti oldukça uzun bir süreci kapsamaktadır. 6. yüzyılda ortaya çıkan satranç Hindistan üzerinden doğrudan Batı coğrafyasına gelmediğinden Hintli tüccarların getirmiş olabilme ihtimali çok olası görünmemektedir. Ancak, coğrafi yakınlıktan ötürü pek tabii İran'dan gelmiş olabilir ya da Gürcü tarih yazıcılığının aksine Arap hâkimiyeti döneminde de Gürcistan’a girmiş olabilir.

${ }^{3}$ Gürcü edebiyat tarihi için önemli olan ve 12. yüzyılda kaleme alınmış Amirandarejaniani isimli eserde Amir İamaneli isimli birisinin dönemin en önemli satranç ustası olduğuna dair bilgiler mevcuttur. https://sites.google.com/site/chadraki11/pigurebis-sv
} 
Yukarıda da bahsedildiği gibi, Ganj kralı tarafından Pers şahı Sâsâni hükümdarı Hüsrev I. Anuşirvan'a (MS 531-579) gönderilen hediyeler arasında tahtadan yapılmış bir satranç takımının bulunması Hüsrev I. Anuşirvan döneminde satrancın İran'a girdiğini göstermektedir (Ahsan, 2012, s. 253). Hindistan ve İran arasındaki diplomatik ilişkileri de gösteren bu hikâyeye göre, Hindistan'dan zengin hediyeler ile gelen bir elçinin hediyeleri arasında Kelile ve Dimne kitabı, Hint kınası ve satranç tahtası vardır (Sivrioğlu, 2013, s. 239). ${ }^{4}$ Ancak bu hediyelerin yanı sıra elçi, Anuşirvan'a iletilmek üzere bir mektup da getirmiştir. Bahsi geçen bu mektup Hindistan tarafından İran'a açık bir meydan okuma mahiyetindedir. Hindistan tarafından Sâsânilere iletilen mesaj şu şekildedir:

Bilimin peşinde koşanlara dama tahtasını önünüze koymalarını teklif edin ve her adamın bu ince oyunun nasıl oynandığına dair fikrini ifade etmesine izin verin. Her bir parçayı nasıl ve hangi kareye taşınması gerektiğini açıklayın. Piyade askerini, fili ve savaş arabası ve at gibi ordunun geri kalanını ve vezir ile şahın hareketlerini teşhis edebilmelidirler. Bu incelikli oyunun nasıl oynandığını keşfederlerse, diğer tüm bilge insanları geride bırakacakları için memnuniyetle size talep ettiğiniz haracı göndereceğim. Öte yandan, İran'ın önde gelen adamları bu bilimde tamamen başarısız olursa ve bu konuda bizimle eşit olmadığını kanıtlarsa, artık bu topraklardan ve topraklarımızdan herhangi bir vergi veya haraç alamayacaksınız. Öte yandan siz, haraç ödemeye razı olacaksınız; çünkü bilim herhangi bir servetten daha üstündür (Eales, 1985, s. 25).

Hüsrev I. Anuşirvan bunun üzerine elçiden bir hafta süre istemiş ve veziri Büzürcmihr’i bu konuda görevlendirmiştir. Büzürcmihr de ilk olarak bir gün bir gece boyunca satranç taşlarını ve satranç tahtasını incelemiştir. Nihayetinde de oyunun sırrına vâkıf olmuş ve taşları doğru şekilde sıralamayı başarmıştır. Bunun üzerine Hint elçisine durum iletilmiştir. Hint elçisi satrancın sırrına ulaşıldığını görünce utanmış ve Büzürcmihr’in eşi benzeri olmayan bir insan olduğunu söylemiştir. Bu şekilde, Hintliler Sâsânilere vergi vermeye devam etmişlerdir (Eales, 1985, s. 25; Sivrioğlu, 2013, s. 242). 7. yüzyılın sonunda yazılan bir Sâsâni kaynağında ise bu hikâyenin devamı şu şekilde anlatılmaktadır. Yine İran'a gelen Takhtaritus isimli Hint elçisi vardır ve bu elçiyi İran'a gönderen ise Dewasarm isimli bir Hint hükümdarıdır. Burada Wajurgmitr olarak adlandırılan Büzürcmihr, vezaret makamındadır. Satranç oyununda Büzürcmihr galip gelir ancak bununla da yetinmez ve tavla olduğu düşünülen nard/nerd oyununu icat eder. Ardından da Sâsâniler tarafından bu oyunun sırrını çözmeleri için Hintlilerin sarayına karşı hamle olarak gönderir. Bu metnin önemi mühimdir

\footnotetext{
${ }^{4}$ İlgili kısımda Sivrioğlu, bu hikâyenin Mesudi ve Firdevsî’de farklı farklı anlatıldığının altını çizmektedir. Hüsrev I. Anuşirvan'a gelen hediyeler ile ilgili bilgileri Mesudi'den, hikâyeyi ise Firdevsî'den örnek göstererek anlatmıştır.
} 
çünkü bahsi geçen bu kaynakta anlatılan hikâyenin dışında dönemin satrancının da altmış dört karelik bir tahta üzerinde oynandığı ortaya çıkmaktadır (Eales, 1985, s. 25-26; Murray, 1913, s. 151).

Birçok kaynağa göre İran, satranç ile 6. yüzyılda tanışmış ve oyun yüzyıllar boyunca bu coğrafyada yeni oyunların eklenmesiyle çeşitlenmiştir. Ancak, buna rağmen İran'da satrancın yaygın olarak oynanması Sâsâni döneminin sonlarına doğru gerçekleşmiştir. En azından 6. yüzyıldan itibaren satrancın temel formunun, bugün bilinen taş düzeneğinde olduğu gibi iki tarafında sekiz kare ile toplamda 16 kareden oluşan bir tahtada oynanıyor olduğu anlaşılmaktadır (Utas ve Dabirsiaqi, 1991, s. 393-397).

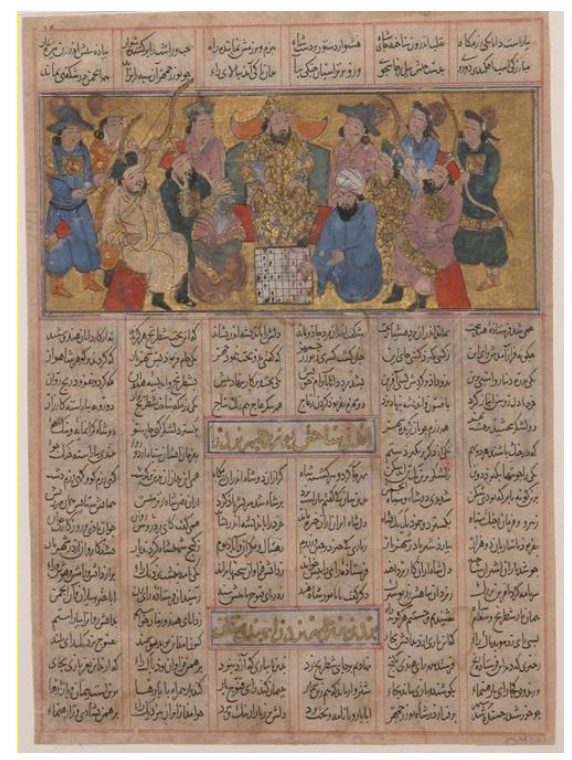

Şekil 3. Firdevsî’nin Şahnâme'sinde Büzürcmihr’in satranç oyunu (The Met)

10-11. yüzyıllar arasında Gürgan, Gilar, Rey, Taberistan, Deylem ve Cibâl bölgelerinde hüküm süren Ziyaroğulları'ndan Keykâvus, oğlu Gilân Şah'a nasihat vermek için 1082 senesinde Kabusnâme isimli bir kitap yazmıştır. Siyasetnâme türünün önemli örneklerinden biri olan eserinde satranç ile ilgili ayrı bir bölüm oluşturmuştur. Keykâvus'un oğluna verdiği ögütlerden biri karşımıza şu şekilde çıkmaktadır;

İmdi sarhoşla ve ayıkla acı söğmekten şakadan ve kötü sözden sakın, hele tavla oynanıyorsa ya da satranç. Çünkü bu iki oyun sırasında insana gönül darlığı çok gelir, özellikle tavla da zar gelmezse ya da satrançta açmaza düşmüşse. O sırada mizah tehlikelidir, değme kişi kaldırmaz, öyleyse şaka etmemek gerekir, Sonra satranç ve tavla oynamayı âdet edinme, eğer oynarsan arada bir oyna; onu da para ile oynama... Para ile oynama çünkü para ile oynamak kumardır (Keykâvus, s. 175).

Keykâvus'un kaleme aldığı bu satırlar aslında bu dönemde satranç ve tavlanın sıklıkla oynandığını gösterdiği gibi bu süreçte herkes tarafından caiz görülmediğini de 
düşündürmektedir. Ancak yine de tavlaya karşı olan tutumun satranca karşı olmadığını da belirtmek gerekir (Altınay, 2009, s. 180). Keykâvus b. İskender aslında teolojik geleneği izleyerek satranç ve tavlaya düşkün olmamak gerektiği konusunda oğluna uyarı ve telkinlerde bulunmuştur (Utas ve Dabirsiaqi, 1991, s. 393-397). Keykâvus satranç oynanmasına tamamen karşı olmadığını da şu cümleleriyle ifade eder:

Satrancı para için oynama, ama bir tavuk için, bir eğlence için ya da buna benzer bir şey için oyna ki şahane bahane olur sohbete ulaşmaya... Ondan sonra senden ulu kişi ile tavla ya da satranç oynarsan edep odur ki zarları önce o atsın, satranç ise önce o oynasın (Keykâvus, s. 175-176).

Anlaşıldığı kadarıyla, satranç hem doğu hem de batıda zaman zaman dinî zümreler tarafından hoş karşılanmasa da kendisine bir yaşam alanı bulmuş ve bir şekilde bu dinî kaygıların önüne geçebilmiştir.

\section{Abbasîler Döneminde Satranç}

Satrancın Araplara geçişi, oyunun kurumsallaşması ve bugünkü şekline yakın bir form alarak Araplar vasıtasıyla Batı'ya yayılmış olması sebebiyle önemlidir (Altınay, 2009, s. 179). Abbasîler döneminde satranç, tavla ve dama gibi zekâ geliştiren oyunların sosyal hayatta önemli bir yeri vardır. Mezkûr dönemin en ünlü satranç oyuncuları olarak Adlî, Razî, Maverdî ve Sûlî’yi saymak mümkündür (Ahsan, 2012, s. 252). Teknik manada ilk satranç monografisi Kitâbü'ş-Şațanc ismiyle Ebü'l Abbas Ahmed el-Adlî tarafından 854/855 yılında yazılmıştır (Altınay, 2009, s. 180). Halife Mütevekkil'in (847-861) de bizzat bulunduğu bir satranç maçında uzun bir süredir satranç liderliğini elinde bulunduran Adlî, Razî̀ye yenilmiştir. Halifeler arasında ise ilk satranç oynayanın Harun Reşid ${ }^{5}$ olduğu bilinmektedir (Murray, 1913, s. 195; Ahsan, 2012, s. 252). Ayrıca, Harun Reşid'in oğlu Emin de (öl. 813) babası gibi bir satranç oyuncusuydu (Murray, 1913, s. 196).

Harun Reşid ve Mütevekkil'in dışında diğer Abbasî halifelerinden Mut'azıd'ın da satranç oynadığı bilinmektedir. 833-837 yılları arasında doğmuş ve 899 senesinde vefat etmiş olan ve Kindî ekolüne sahip olan Ahmed Serahsî halife Mu'tazıd'ın nedimliğini yapmıştır (Kutluer, 2000, s. 230). İlgili yerlerde de bahsedileceği üzere bir nedimin mutlaka bilmesi gereken satrancı Ahmed Serahsî’nin de iyi derecede bildiği aşikârdır. Çünkü kaleme almış olduğu birçok eserin dışında satranca ait eserinin de olduğu bilinmektedir (Makdisi, 2007, s. 298). Yine aynı şekilde Abbasîler döneminde çok sayıda satranç turnuvası düzenlenmiştir.

\footnotetext{
5800 yılında Harun Reşid'in iyi bir satranç oyuncusu olarak bilinen Fransız Kralı Charlemange'ye elçileri aracılığıyla satrancı hediye olarak göndermesi ile ilgili çeşitli iddialar mevcuttur. Ancak, böyle bir kayıta ya da bilimsel çalı̧̧maya rastlayamadığımızı belirtmek isteriz.
} 
819 senesinde Horosan'da Cabir el-Kufî ve Ziryab el-Hattan arasında geçen karşılaşmayı Halife Me'mûn'unda izlediği bilinmektedir. $\mathrm{Bu}$ dönemde, tacirlerin cariyelere satranç öğretmesini satrancın bu dönemdeki önemine örnek olarak gösterebilmek mümkündür (Yıldırım, 2016, s. 360). Abbasîler döneminde yapılan bu satranç turnuvaları adeta tiyatroyu andıran bir atmosferde halk tarafından heyecanla takip edilen bir eğlence oyunuydu.

869-871 yılları arasında Bağdat'da doğan ve bu nedenle Bağdâdî nisbesiyle anılan; ayrıca Abbasîler döneminin en önemli satranç ustası olması sebebiyle "Şatrancî” nisbesiyle de tanınan edip, şair ve tarihçi kimliğiyle ön plana çıkan Türk asıllı Ebû Bekir Sûlî, Türk İslâm dünyası için önemli bir isimdir. Dönemin satranç ustası Muhammed b. Ahmed el-Maverdî’ye karşı galibiyet alması ona büyük bir itibar kazandırmıştır (Ünver, 2001, s. 15-20; Özaydın, 2009, s. 492). Cürcan'ın Türk hâkimi Sûl Tegin'lerden olan Sûlî’nin Kitâbü'ş-Şațranc isimli kitab1 mevcuttur (Turan, 2005, s. 466). Abbasîler döneminde nedimlik görevi de yapan Sûlî’nin satrançtaki yeteneği diğer yeteneklerine göre daha değerliydi. Zira erken Abbasî döneminde, halifeye arkadaşlık eden nedimler, tahammül, tevazu, sırdaşlık ve kelamı kısa tutma faziletleriyle kendini eğiten kişiler olmaları gerektiği gibi onların av zamanlarında, satranç oyunlarında ve edebiyat sohbetlerinde de emrine amade olmalıydılar (Chejne, 1965, s. 335; Y1ld1z, 2018, s. 86).

Abbasîler dışında Fâtımîler'de de satrancın varlığını aynı şekilde görmekteyiz (Hillenbrand, 2005. s. 70). Örneğin, Fâtîmî halifelerinden 996-1021 seneleri arasında halifelik görevini icra etmiş, sert mizacı ve katı yönetim biçimiyle tanınan Hâkim-Biemrillâh, halifeliği döneminde halk üzerinde birçok yasaklar getirmiş ve uymayanları ağır bir şekilde cezalandırmıştır. Bu yasaklarından bir tanesi de halkın satranç oynamasına karşı engelleyici tutumu olmuştur (Öz, 1997, s. 199).

\section{Selçuklular Döneminde Satranç}

Büyük Selçuklular döneminde satranç önemli bir spor dalı olmakla birlikte hakkında kaynaklarda son derece kıt bilgiler bulunmaktadır. Selçuklu kaynaklarında satranç ile ilgili bilgiler Abbasîler'de olduğu gibi özellikle nedimler hakkındaki malumatlarla birlikte anlatılmaktadır. Nizâmülmülk'ün sultanın nedimlerinin nasıl olması gerektiğine dair "her daim neşeli, kafadar olup, tavla ve satrancı iyi bilmelilerdir” (Köymen, 1966, s. 55; Ersan, 2006, s. 89; Nizam'ül- Mülk, 2021, s. 124) ifadeleri bunun bir örneğidir. Bu sözler bize Büyük Selçuklu Devleti'nde satrancın sıklıkla oynanan bir oyun olduğunu, özellikle de dönemin sultanları tarafından bu oyunun tercih edildiğini göstermektedir. 
Nizâmülmülk, Siyasetnâme isimli eserinde elçilik kurumunun önemine dair yazmış olduğu kısımda başından geçen bir anısını anlatır. Sultan Alp Arslan döneminde vezirlik yaptığı esnada Alp Arslan'ın Maveraünnehir bölgesine bir sefer yapma hazırlığ içerisindeyken Semerkant Hanı Şems'ül Mülk (Nasr b. Ahmed) ona boyun eğmediğinden Selçuklu yönetimi tarafından kendisine elçi gönderilmiştir. Nizâmülmülk de olup bitene hâkim olabilmek adına sultanın göndermiş olduğu elçinin yanında Dânişmend Eşter'i elçinin yolculuğu için vazifelendirmiştir. Sultanın elçisi Semerkant'a varıp görevini ifa ettikten sonra Semerkant Han’1 Şems’ül Mülk Alp Arslan'ın elçisinin yanına kendi elçisini de koyarak sultanın nezdine göndermiştir. Elçiler sultanın huzuruna vardıklarında Nizâmülmülk dostlarıyla satranç oynadığını ve galip geldiğini, bu galibiyetin neticesinde de rakibine ait bir yüzüğü rehin olarak aldığını yazmaktadır. Yüzüğü sol elinin parmağından să̆ elinin parmağına taktığı anda Semerkant Han'ının elçisinin geldiğini öğrenince satranç takımını ortadan kaldırmıştır (Köymen, 1966, s. 78-79; Taneri, 1967, s. 157-158). Nizâmülmülk'ün bu ifadelerinden de anlaşılacağı üzere zaman zaman kendisinin de satranç oynadığı ve oynamaktan zevk aldığı görülmektedir.

Muhammed b. Ali b. Süleyman er-Râvendi tarafindan kaleme alınan ve Selçuklular tarihinin önemli kaynaklarından sayılan Râhat-üs Sudûr ve Âyet-üs-Sürûr isimli eserde satranç ile ilgili mühim bilgiler bulabilmek mümkündür. Râvendî bu kitabında satranç ile ilgili açmış olduğu başlığı "Padişahlarla Nedimlik Etmek Âdâbının Zikri, Şatranç ve Tavla Oynamanın İzahı” olarak belirlemiştir. İlgili yerlerde de belirtildiği gibi iyi bir nedim olmanın kuralları arasında iyi bir satranç ustası olunması gerektiğini bu bölümde ayrıntılarıyla anlatmıştır. Ancak, Râvendî’yi diğerlerinden farklı kılan özelliği satranç konusunda daha ayrıntılı bilgiler vermek olduğu gibi satrancı bir savaş stratejisi oyunu olarak görmesidir. Müellif, bu konudaki fikirlerini şu şekilde açıklamaktadır:

... Bu oyun, nedimler şahlarla oynasınlar, ordunun merkezinin, să̆ ve sol kanatlarının, yanların nasıl olması lâzım geldiği, bir taraftaki hasım hazırlık yapıp, malzemesini tertip ederken, diğer taraftaki hasımın da gafil olmadığını, her ikisinin de savaşta azimkâr olmalarını onlara telkin etsinler diye icat edilmiştir (Râvendi, 2020, s. 376).

Râvendî aslında satrancı sultanların savaş meydanlarındaki hamleleri için uygun bir hazırlık süreci olarak görmüştür. Zaten, "bu oyundan edilecek istifadeler çok ve sayısız ise de, asıl maksat harbin esaslarıdır" (Râvendi, 2020, s. 382) ifadeleri de bu durumu açıklamaktadır. Râvendî, satrancın Hindistan'dan İran'a geldiği ilk hâlinden bahsettikten sonra vezir Büzürcmihr'in ekleme yaptığı versiyonu da açıklar. Büzürcmihr'in satrancında taş sayısı aynı iken taşların yerleştirme sıralaması farklıdır. Büzürcmihr'in oluşturduğu bu oyuna göre 
satranc1, zarla oynamak da mümkündür. Eğer zar ile oynanacaksa zarlar atıldıktan sonra kimin zarı daha büyük bir sayıda gelirse o kişi ilk zarı atar ve zara göre oyun oynanmaya devam edilir. Râvendî, Büzürcmihr'in oyununu anlattıktan sonra Rum hâkimlerinin oyunlarını da sırasıyla tarif eder. Râvendî satranç faslını bitirirken bu oyunu oynayanların satranç yüzünden namazı kaçırmamaya gayret etmeleri gerektiğini belirterek bu konuyu sonlandırır (Râvendi, 2020, s. 377- 384).

Orta Çă̆ İslâm dünyasından Avrupa’ya intikal eden satranç, anlaşılacağı üzere yüksek düzeyli devlet adamı ve âlimlerin eğlencelerinde oynadıkları ve değer verilen bir oyun türüydü (Turan, 2005, s. 434, 445). Selçuklu sultanlarının boş zamanlarını geçirmek için seçmiş oldukları meşguliyet alanlarının içerisinde avcılık ve cirit dışında satranç oynamak da vardır (Turan, 1958, s. 28). Örneğin, İbn Bibî I. Alâeddin Keykûbâd'ın satrancı ve tavlayı iyi bir seviyede oynadığını ifade etmektedir (İbn Bibi, 1996, s. 247; Yıldız, 2018, s. 90).

Mevlânâ'nın Divan-1 Kebir isimli eserinin muhtelif ciltlerinde de satranç ile ilgili çeşitli kayıtlara ulaşmak mümkündür (Ersan, 2006, s. 89). Mevlânâ eserlerinde, satrancı metafor olarak kullanmayı da tercih etmiştir. Mevlânâ'nın “Can padişahı, satranç oyunundaki piyade gibi haneden haneye sürüyor bizi; acaba kazandı mı mat mı oldu? Çünkü sınanan biziz" sözleri buna sadece bir örnektir (Mevlânâ Celâleddin, 1992, s. 391). Yine hayat1, ciddiye alınarak oynanması gereken bir satranç oyununa benzetmesi de Mevlânâ'nın metaforlarından bir diğeridir (Kazanç, 2019, s. 85). Ancak bu metaforik anlamların dişında Mevlânâ, halkın boş zamanlarını değerlendirmek için erkeklerin tavla ve satranç oynadıklarını kaydetmektedir (Özbek, 2001, s. 49). Bunların dışında, Selçuklu kervansaraylarında (Dârü'zziyâfe) ilim insanları için kütüphane kurulmasının yanı sıra yolcular için satranç takımlarının bulundurulması da bu dönemin kültür ve medeniyet seviyesini göstermesi bakımından kayda değer olduğu gibi, satrancın halk arasında da oldukça yaygın bir oyun türü olduğunu göstermektedir (Turan, 2005, s. 357).

\section{Timurlular Döneminde Satranç}

Emir Timur'un âlimlere çok önem verdiği, her firsatta âlimlerle birlikte olduğu ve satrancı büyük bir ustalıkla oynadığı tüm kaynaklarda ortak bir şekilde ifade edilmektedir (Berl, 1999, s. 246; Barthold, 2017, s. 188). Timur'un satrancı sadece düşünme yetisini ilerletebilmek amacıyla değil aynı zamanda stresli zamanlarında rahatlamak amacıyla da oynadığı bilinmektedir. Satrancı oldukça iyi bir seviyede oynadığı için kendisine karşı çıkacak rakip bulamadığı rivayet edilmektedir. Timur'un daha büyük bir tahtada ek taşlar ekleyerek satranca yeni bir form verdiği konusu da Timur ile ilgili en dikkat çeken 
hususlardan bir diğeridir. Kaynaklarda genellikle büyük satranç tahtasında (satranç el-kebir) oyununu oynadığı belirtilen Emir Timur'un oluşturduğu büyük satranç tahtası on bire on kareden oluşmaktaydı. Bu satranç tahtasında iki deve, iki zürafa, iki boğa, iki aslan, iki debbâde'den (kale surlarını yıkmak için kullanılan araba/silah) oluşan taşlar vardı. ${ }^{6}$ Timur'un satranç düzeneği bu çalışma boyunca anlatılan diğer satranç düzenekleri ile kıyaslandığında bir hayli farkl1lık göstermektedir.

Muhammed b. El- Akîl el-Haymî, Zeyneddin el- Yezdî ve fakih Alâeddin et-Tebrizî gibi isimler Timur'un birlikte satranç oynadığı kişilerin başında gelmektedir. Alâeddin etTebrizî ve Timur'un bahsi geçen satranç sistemi ile satranç oynadığı bilinmektedir. Hatta bir gün birlikte bu oyunu oynarken rakibine "Şah-Ruh" yaptığı sırada Timur'a erkek çocuğu olduğu ve Ceyhun nehrinin kıyısına inşa ettirilmekte olan şehrin tamamlandığı müjdesi verilmiştir. Bunun üzerine Timur'un da oğluna Şahruh; şehre ise Şahruhiyye ismini verdiği rivayet edilmektedir. Emir Timur'un Alâeddin et-Tebrizî'ye “Ben nasıl ki saltanat ve siyasette benzersizsem sen de satrançta öylesin" dediği de bilinmektedir (Yüksel, 2004, s. 111).

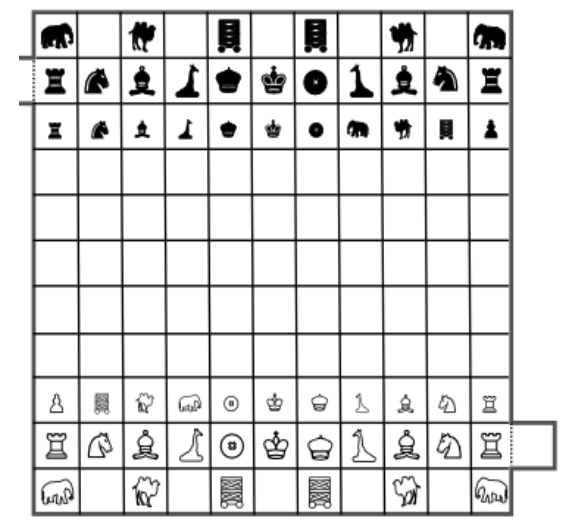

Şekil 4. Timur satrancının düzeneği (Indiana University Bloomington, 2018)

Dukas Kroniğinde, 1402 Ankara Savaşı sonrasında Yıldırım Bayezid'in Timur tarafından esir alınmasının ardından Timur'un otağına getirildiğinde Timur'un satranç oynayarak onu önemsemediğini göstermeye çalıştı̆̆ına dair ifadelerin bulunması aslında hem Timur'un satranç oynamayı çok sevdiğini hem de döneminde satranç oynadığının herkes tarafından bilindiği anlamına da gelmektedir (Y1lmaz, 2018, s. 474). Timur'un satranca olan düşkünlüğü fethettiği yerlerde ilk olarak o bölgenin en iyi satranç bilen kişisini karşısına çıkartıp oyun oynamasından da bellidir. Bununla birlikte ölmeden önce satranç oynamayacağına dair Otrar'da tövbe ettiğine dair kayıtlar da bulunmaktadır (Aksoycuk, 2019, s. 8-9).

6 "İki deve, iki bekçi, iki top, iki zürafa, bir vezir ve birkaç tane daha taştan oluşan bu oyun günümüzde Timurlenk satrancı olarak bilinen en zor oyunlardan biridir" (Bland, 1852, s. 5; Marozzi, 2006, s. 110-111). 


\section{Satrancın Avrupa'ya Geçişi}

Satrancın Avrupa'ya geçişi konusunda farklı görüşler bulunmakla birlikte ağırlıklı olarak Hindistan'dan İran'a geçtiği ve Müslüman dünya tarafından Avrupa'ya transfer edildiği kabul edilmektedir (Murray, 1913, s. 27). Satrancın, Arap fetihleri sonucunda Emevîler aracılığıyla Kuzey Afrika - Endülüs - İtalya (Sicilya) güzergâhı üzerinden batıya yayılmış olduğu görüşü dışında az da olsa Vikingler aracılığıyla Avrupa'ya yayılmış olduğu görüşü de hâkimdir (Altınay, 2009, s. 179). Genel kanıya göre Avrupa'ya yayılma güzergâhı ise, Hindistan, İran ve Arap topraklarından ilerleyerek İspanya, İtalya ve Almanya'ya ulaşması şeklindedir (Yalom, 2005, s. 17-18). Avrupa'ya satrancın ilk gelişi ile ilgili bilgilere ulaşmak ise dönemin edebi eserleri vasıtasıyla mümkün olmaktadır.

Haçlı seferlerinin doğu ve İslâm dünyası ile temasının sonucunda Haçlılar, doğu medeniyetinin önemli buluşları ile tanışmışlardır. 11. yüzyıl ve akabindeki dönemlerde de Haçlıların satranç ile tanışıp oyunu Avrupa'ya taşınmasındaki rolleri mühimdir (Demirkent, 1997, s. 284-285). 11. yüzyılla birlikte satranç artık neredeyse tüm Avrupa kıtasında oynanan bir oyun haline gelmiştir. Avrupa'ya geçişi çok daha erken tarihlerde olsa da satrancın Kuzey Avrupa'ya geçişi de 11-12. yüzyıla denk gelmektedir. 1831 yılında Lewis adasında bulunan Lewis satranç figürleri/taşları (Lewis chessmen) İskandinav yarımadası için satrancın Kuzey Avrupa'daki varlığını göstermektedir. Bahsi geçen bölgede 11. yüzyılda Viking diasporası olduğundan ötürü de bu bölgede bulunan Lewis satranç figürlerinin Vikingler aracıllığıyla Avrupa'nın kuzey kıyılarına geldiği düşünülmektedir (Schulte, 2017, s. 2).

Satrancın Avrupa'ya geçiş döneminde, kilise bu oyunu ilk zamanlar bir kumar oyunu olarak kabul etse de satranç revaçta bir oyun olma özelliğini korumuş ve gün geçtikçe tercih edilirliği artmaya başlamıştır. Orta Çağ Avrupa satrancı, 15. yüzyılın ikinci yarısına kadar, Müslüman dünyasının oynadığı satranç ile aynı kurallara göre oynanmıştır. Daha sonra oyunun temposunu hızlandırmak için rok atma, geçerken alma ve kraliçe (vezir) ve piskoposun ( $f i l$ ) güçlerini artırma gibi bazı yenilikler tasarlanmıştır. 16. yüzyılın ortalarına gelindiğinde ise, bugün bildiğimiz şekliyle satranç oynamanın temel kuralları standart hale gelmiştir (Wilson, 1981, s. 1). Modern satrancın 15. yüzyılın sonlarında İspanya Valensiya'da şekillendiğini iddia eden Calvo (1998), Orta Çă̆’da satrancın ülkeden ülkeye değişik kurallar içerisinde oynandığını belirtir.

Avrupa'da şövalyelik çağındaki her öğrenci, saray toplumunun eğitiminde ve eğlencesinde oyunların yanı sıra müzik ve mızrak dövüşünün oynadığı rolün farkındadır. 
Oyunlar arasında satranç, şövalyelerin ve kralların oyunu olarak başı çekmiş ve 12. yüzyıldan 15. yüzyıla kadar bir daha asla elde edemediği bir üne sahip olmuştur (Gamer, 1954, s. 734).

1106'da Hıristiyanlığa geçen bir İspanyol Yahudisi olan Petrus Alfonsi, iki kültür arasında ideal bir bağlantı kurmaya çalışıyordu. Hayatının ilerleyen zamanlarında İngiltere'ye gitmiş ve burada Kral I. Henry'nin kişisel doktoru olarak görev yaptığı gibi Arap astronomi bilgisini burada tek öğrencisi olan Walcher Prior of Malvern'e aktarmıştır. 12. yüzyılda yazmış olduğu Disciplina Clericalis isimli kitabı Kelile ve Dimne'deki gibi Doğu öykülerinden oluşmaktaydı. Petrus Alfonsi, Clerk's Instruction (Disciplina Clericalis) adlı kitabında şövalye başarısını; binicilik, yüzme, okçuluk, boks, satranç ve şiir yazma olarak sıralamıştır (Eales, 1985, s. 53). Yine Orta Çağ Fransa'sının epik şiir biçimi olan Chanson de geste'de Olivier de la Marche'nin satranç ile ilgili vermiş olduğu bilgiler arasında satranç tahtası önünde maç esnasında rakiplerin birbirleriyle uyuşamadıklarına dair bilgiler vardır. Huizinga bu durumu, 15. yüzyılda hükümdarların satranç sebebiyle kavgaları da zaten sıklıkla karşılaşılan bir durumdur şeklinde açıklar (Huizinga, 1997, s. 22).

1283 senesinde Kastilya Kralı, Toledo, León, Galiçya, Badajoz, Sevilla, Kurtuba, Murcia, Jaén ve Algarve'nin lütfuyla X. Alfonso tarafindan kurdurulan Toledo Çevirmenler Okulu'nda Arapça metinlere dayanarak çevrilen ve satrancın kurallarını içeren Libro de los juegos (Book of Games -Oyunlar Kitab1) isimli eser Avrupa edebiyat ve bilimsel literatürü açısından ilk satranç kitabıdır (Musser, 2007, s. 30). Yine bu dönemde Doğu'dan Avrupa'ya gelerek Toledo Çevirmenler Okulu'nda çevrilen ve satranç ile ilgili olan bir diğer eser ise Libros de ajadrez, dados y tablas (Satranç, Zar ve Tavla Kitabı) başlığını taşımaktadır (Öztunal1, 2017, s. 1336). Jacopo da Cessole (1250- 1322) tarafından 13. yüzy1l İtalya'sında yazılmış olan Libro di giuocho di scacchi ${ }^{7}$ isimli satranç kitabı da zamanın en ünlü kitaplarından biri haline gelmiştir. X. Alfonso'nun 1283 yılındaki el yazmasına eşlik eden bir parça olarak alınan bu kitap, bize yüksek Orta Çağ Avrupa satrancının bir portresini çizmektedir (Yalom, 2005, s. 60). Yine, bunun dışında 15. yüzyıl Avrupa'sında satranç ile ilgili çok sayıda başka eserler de kaleme alınmıştır (Calvo, 1998).

\footnotetext{
7 Jacopo da Cessole'nin Libro di giuocho di scacchi isimli kitabı Jean Vignay tarafindan Latince orijinalinden Fransızca'ya çevrilmiştir. Kitap daha sonra ise The Game and Playe of the Chesse başlığıla İngiliz diplomat ve yazar William Caxton tarafından Fransızca'dan İngilizce'ye çevrilmiştir. Bahsi geçen bu kitabın ilk baskısı 1476 civarında, ikincisi baskısı ise 1483 senesinde yapılmıştır (Knowles, 1954, s. 417).
} 


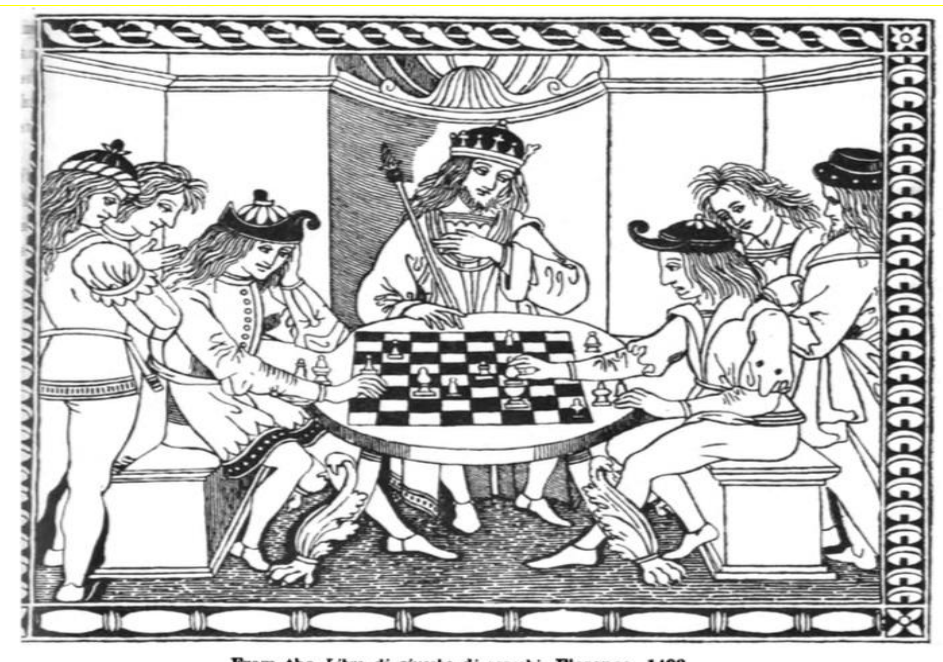

Şekil 5. Libro di giuocho di scacchi isimli eserden bir görsel (Murray, 1913, s. 547)

X. Alfonso'nun Libro de los juegos isimli kitabı, insanların dertlerini unutmak ve mutlu olabilmek için kendilerine çeşitli yollar aradıklarını ve bu sebeple de birçok farklı oyun keşfettiklerini anlatmakla başlar. İlk olarak at sırtında cirit ve mızrak firlatmak, kalkan ve mızrak almak, yay ve okla atış yapmak, eskrim, dövüş, koşma, zıplama, taş veya dart firlatma gibi birbirinden farklı birçok oyundan bahsedilir. Fark edilebileceği üzere bunlardan bazıları askerî faaliyetler olup Orta Çağ yaşam biçimini de göstermektedir. Ardından da satranç ve tavla zaman fark etmeksizin gece ve gündüz oturarak oynanan oyunlar olarak tasnif ve tarif edilir. Ayrıca kitapta, satrancın zarlardan ve masada oynanan diğer oyunlardan daha asil bir oyun olduğuna dair vurgu yapılır. Kitapta, satranç tahtasının kaç kareden oluştuğu, taşların adlarının neler olduğu, oyunun nasıl oynandığı, taşların avantajlarının neler olduğu, oyuncuların oyunu kazanmak için nasıl hamleler yapmaları gerektikleri gibi satrancın kuralları anlatılır. Örneğin; satranç tahtası üzerinde toplamda otuz iki taş olması ve bunların iki farklı renkte olması gerektiği tarif edilir. On altı taş yatay şekilde tahtanın bir ucuna diğer renkte olan on altı taş ise karşı tarafa yani tahtanın diğer ucuna dizilmelidir şeklinde satranç tahtası düzeneği anlatılır. Ancak bundan daha ilgi çekici bilgi ise taşlar anlatılırken on altı taştan sekizinin daha küçük olduğu, çünkü bu küçük olan parçaların orduya giden askerleri temsil ettiğinin yazılmasıdır. Pek tabii büyük olan taşlardan bir tanesi orduların efendisi olan kraldır (Musser, 2007, s. 106-107). 


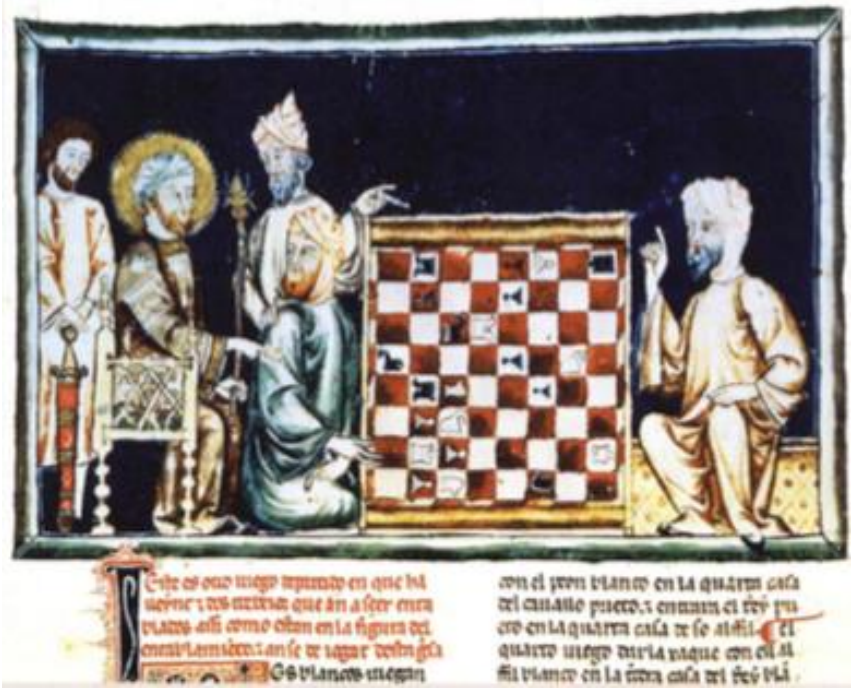

Şekil 6. X. Alfonso'nun iki satranç oyuncusuyla bir satranç problemi hakkında konuşması (Gordon, 2009, s. 22)

Yukarıda anlattığımız bilgilerden de anlaşılacağı üzere, Orta Çă̆ İspanya’sının satrancı büyük bir ilgi ile karşıladığı o döneme ait bilgiler ve kaynakların yoğunluğu sayesinde kendini gösterebilmektedir. Endülüs Müslümanlarından İşbiliye yani Sevilla'da yaşayan ve bu bölgenin itibarlı bir ailesi olan İbn Zuhr ailesine mensup Ebu Bekr ez- Zuhrî elKureşî, 12. yüzyılın sonları ve 13. yüzyılın başlarındaki (öl. 1214-1224 arası) fikıh ve edebi ilimler alanında önde gelen isimlerden birisidir. Kendisinin çok iyi satranç oynadığ Sevilla' da kendisinden daha iyi satranç oynayan herhangi birisinin olmadığı, bu sebeple de Ebu Bekr ez-Zuhrî eş-Şatrancî olarak tanındığı bilinmektedir. Hatta bu şekilde tanınmaktan oldukça rahatsız olduğunu ve başka bir uğraş alanıyla isminin anılmasını istediğini, bu nedenle de başka bir alan bulmak ve onunla uğraşma gereği hissettiğini söyler. Bu düşüncesinden dolayı, tıp okumaya başlamış ve kısa süre içerisinde tıp ilmiyle adı anılmaya başlamıştır (Makdisi, 2007, s. 304, 306). Ebu Bekr ez- Zuhrî el-Kureşî ile ilgili var olan bu bilgilerle birlikte, İspanya sınırları içerisinde Müslümanlardan alınan satrancın hâkimiyet gücünün hâlâ Araplarda olduğunu anlıyoruz. Ebu Bekr ez- Zuhrî el-Kureşî’nin satranç ile anılmak istememesinin birçok sebebi olabilir. Ancak, klasik Avrupa tarih yazımında burada yaşayan Müslümanların satrancı oynadıklarıyla ilgili bilgiler neredeyse yok denecek kadar az olduğundan bu durum kayda değer bir bilgidir.

Kutsal Roma İmparatorları ve Roma Katolik Kilisesinin, bir yandan satrancın eğitici bir eğlence, diğer yandan mahvolmaya giden yol olduğu tartışması Orta Çağ satrancı için bir duraksama dönemi yaşatmamış, satranç varlığını devam ettirmeyi başarmıştır (Yalom, 2005, s. 59). Orta Çağ Avrupa'sında satranç her ne kadar Müslüman dünyasının oynadığı şekilde 
oynanmaya devam etse de İslâm kültürünün bir parçası olarak görüldügüñnden oyunu oynayanlar kilise tarafından 1061 senesinde aforoz edilmişlerdir. Bundan sebeple 1475 senesinden itibaren taşların şekli değiştirilmiş ve Avrupa'da kraliçe vezirin yerine, papazlar fillerin yerine, şövalyeler ise atların yerine kullanılmaya başlanmıştır (Altınay, 2009, s. 178).

Bugün Avrupa'da, modern satranç oyununda oynanan taşların anlamları satranç tarihi çalışan araştırmacılar tarafından Orta Çağ dönemi ile ilişkilendirilmektedir. Çünkü satranç beceri, mantık ve strateji oyunundan daha fazlasıdır. Oyun kendi içerisinde, Orta Çağ dönemi yönetim ve yaşam tarzları hakkında ipuçları bulundurmaktadır. Orta Çağ dönemine gelindiğinde yukarıda da ifade edildiği üzere taşların yapıları değiştirilmiş bu şekilde Orta Çağ feodalizmi ile birlikte satranç oyununa da sosyal bir boyut kazandırılmıştır (Yalom, 2005, s. 14). Satranç tahtasında piyon (pawn) zaman zaman değerli parçaları korumak için feda edilebilir bir taş görevi üstlenmektedir. İşte bundan hareketle piyon satranç tahtasında serfleri ve işçileri temsil etmektedir. Bir satranç tahtasındaki kale (rook/castle) bir evi sembolize etmektedir. Orta Çağ'da kaleler hem ev hem de önemli bir sığınak mekânlarıdır. Satranç tahtasındaki at (knight: şövalye) görevi rütbeli kişileri korumak olan Orta Çağ’ın profesyonel askerini temsil eder ve bir satranç oyununda her iki tarafta da ikişer tane vardır. Satrançtaki atlar piyonlardan daha önemlidir, ancak filler, vezir ve şah kadar güçlü değillerdir. Satranç oyunundaki amaçları daha önemli taşları korumaktır. Ayrıca, piyonların yapabildiği gibi bu taşları kurtarmak için oyuncu tarafından feda edilebilirler. Satranç tahtasındaki fil (bishop) Avrupa feodalizminde kiliseyi temsil eden piskoposu sembolize etmektedir. Orta Çă̆'da kilisenin gücü günlük yaşamda önemli rol oynadığından satranç tahtasında da yerini almıştır. Vezir (queen) taşı Avrupa Orta Çağ ve modern satrancında kadını temsil etmektedir. Orta Çağ feodalizminde pek çok kraliçe kralın sahip olduğu güçten daha fazla güce sahiptir. Bu sebepten oyunda da sadece bir adet bu taştan bulunmaktadır ve hareket yeteneği diğer taşlara oranla daha geniştir. Doğu medeniyetinde bu taş vezir olarak belirlenmiş olsa da her iki medeniyette de en güçlü taş budur. Şah (king), tahtadaki en uzun taştır ve Orta Çağ yaşamında olduğu gibi satranç tahtasında da savunulur. Orta Çağ'da, kralın/şahın teslim olması, krallığın veya imparatorluğun işgalci ordular karşısında yenik düşmesi anlamına gelmektedir. Kralı düşmanlardan korumak, en düşük serften en yüksek rütbeli memura kadar herkesin yararınadır. Bu sebepten ötürü, şah satrançtaki en önemli taştır, ancak en güçlü taş değildir. Tüm taşlar şahı korumak zorundadır çünkü şahınızı korumazsanız oyunu kaybedersiniz (Oriesek ve Schwarz, 2008, s. 9; Mansfield, 2009, s. 19). 


\section{Sonuç}

Bu çalışmada, Hindistan'da ortaya çıkan ve tüm dünyayı kısa bir süre içerisinde dolaşan satranç oyununun serüveni ve Orta Çağ dönemindeki popülerliği anlatılmaya çalışılmıştır. Milattan önceki dönemlerde satranca ait bir takım arkeolojik buluntular var ise de genel görüşe göre MS 6. yüzyılda Hindistan'da ortaya çıkan satrancın yolculuk hikâyesinde ilk durağı İran olmuştur. Orta Çă̆'ın dinamik yapısından nasibini alan satranç, özellikle Hindistan'dan İran'a gelmesinin akabinde form değiştirmiştir. Satranç İran'da çeşitli oyun eklemeleriyle gelişim göstererek belirli bir forma dönüşmüştür. İran'dan sonra Arapların da tanıştığı satranç böylece daha hızlı bir biçimde tüm dünyaya yayılmıştır. Hükümdarların oynamayı tercih ettikleri satranç, ortaya çıkıp şekillendikten sonra Orta Çağ yaşam tarzının ipuçlarını veren bir oyun türü olmuştur.

Orta Çağ, Avrupa için karanlık ancak Doğu medeniyeti için aydınlık olan, günümüzün temellerinin atıldığ 1 ve birçok siyasî ve sosyal olayın hareketli şekilde yaşandığı bir süreçtir. $\mathrm{Bu}$ yüzden, satrancın şekillenmesi de bu süreçte gerçekleşmiştir. İslâm ülkelerinde şah ve vezir taşlarıyla var olan formunu devam ettiren satranç Avrupa'da kral ve kraliçe taşlarına dönüşmüş ve taşların şekilleri de ona göre değiştirilmiştir. Taşlar, bulundukları medeniyetlerin yaşam tarzlarını benimsemişlerdir. Bu şekilde satranç yer aldığı toplumun siyasî ve dinî figürlerini bünyesine almayı başarmıştır. Özellikle İslâm’ın Rönesans dönemi olarak da adlandırılan 10. yüzyılın akabinde satranç vakit kaybetmeden doğudan batıya doğru izlediği güzergâhta genel kabul edilen görüşe göre ilk olarak İspanya’ya gelmiştir. Böylece Avrupa'nın en popüler oyunu olma yolundaki ilk adımını atmıştır. Avrupa' da oyunları anlatan ve satranç ile ilgili tafsilatlı bilgileri içeren ilk kitap da yine İspanya'da yazılmıştır.

Satranç doğası gereği bir strateji oyunu olduğu için ilk ortaya çıktığı dönemde savaş öncesi zihin geliştirici bir egzersiz görevi görmüştür. Daha sonra halk arasında yayılmış ve günümüze kadar ulaşmıştır. Bugün dahi, zihinsel gelişimi arttırıcı etkisinden ötürü varlığını muhafaza eden ve eğitim materyali olarak da sıklıkla kullanılan özel bir mantık oyunudur. Bulunduğu yüzyılın gereksinimlerinden ötürü satranç geçmişte, yöneticilere savaş stratejisi geliştirmede veyahut halkı eğlendirmede kullanılmıştır. Bugün ise önemini hiç kaybetmeden, çocukların zihinsel gelişiminde kullanıldığı gibi mühim bir spor dalı olarak varlığını sürdürmektedir. 


\section{Kaynakça}

Africanus Leo. (1896). The history and description of Africa. London: The Hakluyt Society.

Ahsan, M. M. (2012). Abbasiler döneminde sosyal hayat (ev içinde ve açık havada oynanan oyunlar). (M. E. Şen, Çev.). Tarih Okulu, 12, 235-260. (Orijinal çalışma basım tarihi 1979).

Aksoycuk, N. (2019). Emîr Timur, kişisel özellikleri ve askerî dehâsı. Ankara Üniversitesi Sosyal Bilimler Dergisi, 10(2), 5-13.

Altınay, R. (2009). Satranç. Türkiye Diyanet Vakfi İslâm Ansiklopedisi içinde (36, s. 178181). İstanbul: Türkiye Diyanet Vakfı Yayınları.

Altungök, A. (2014). Sâsani kültür ve medeniyetinin İslâm kültür ve medeniyetine etkileri. Tarih Incelemeleri Dergisi, 29(2), 445-487.

Barthold, V. V. (2017). Orta Asya Türk tarihi hakkında dersler (3. bask1). (R. H. Özdem, Çev.). Ankara: Türk Tarih Kurumu Yayınları.

Berl, E. (1999). Attila'dan Timur'a Avrupa ve Orta Asya. (G. Devrim, Çev.). İstanbul: Doğan Kitap. (Orijinal çalışma basım tarihi 1946).

Bland, N. (1852). On the Persian game of chess. The Journal of the Royal Asiatic Society of Great Britain and Ireland, 13, 1-70.

Buzurgmihr masters the game of chess, folio from the first small Shahnama, (Book of Kings) ca. 1300-30. The Met. https://www.metmuseum.org/art/collection/search/449000

Calvo, R. (1998). Valencia Spain: the cradle of European chess. Presentation to the CCI May. http://history.chess.free.fr/papers/Calvo\%201998.pdf

Chadraki Saqartveloshi (2021). Chadraki. https://sites.google.com/site/chadraki11/pigurebissv (Gürcüce).

Chejne, A. G. (1965). The boon-companion in early 'Abbâsid times'. Journal of the American Oriental Society, 85(3), 327-335.

Demirkent, I. (1997). Haçlı seferleri. İstanbul: Dünya Yayıncılık.

Eales, R. (1985). Chess -the history of a game. London: A Batsford Book.

Emir Unsurü'l Maâlî Keykâvus b. İskender b. Kâbus b. Verşmgîr bi Ziyâr. (t.b.). Kabusnâme. C I. (İlyasoğlu Mercimek Ahmed, çev.) Tercüman, 1001 Temel Eser.

Ersan, M. (2006). Türkiye Selçuklularında devlet erkânının eğlence hayatı. Tarih İncelemeleri Dergisi, 21(1), 73-106. 
Gamer, H. M. (1954). The earliest evidence of chess in western literature: the Einsiedeln Verses. Speculum, 29(4), 734-750.

Gizycki, J. (1972). A history of chess. London: The Abbey Library. (Orijinal çalışma basım tarihi 1960).

Gordon, S. (2009). The game of kings. Saudi Aramco World, 60(4), 18-23.

Hillenbrand, R. (2005). İslam sanatı ve mimarlı̆̆ı. (Ç. Kafescioğlu, Çev.). İstanbul: Homer Kitabevi. (Orijinal çalışma basım tarihi 1999).

Huizinga, J. (1997). Ortaçă̆ın günbatımı. (M. A. Kılıçbay, Çev.). Ankara: İmge Kitabevi Yayınları. (Orijinal çalışma basım tarihi 1919).

İbn Bibi. (1996). El evamirü'l- Ala 'iye fi'l- umuri 'l- ala 'iye (Selçuk name-I). (M. Öztürk, Çev.). Ankara: Kültür Bakanlığı Yayınları.

Josten, G. (2001). Chess- a Living Fossil. Cologne. http://history.chess.free.fr/papers/Josten\%202001.pdf

Kazanç, F. K. (2019). Mevlânâ'nın düşünce sisteminde sebep kavramı ve sebeplilik kuramı üzerine bazı değerlendirmeler. Ondokuz Mayıs Üniversitesi İlahiyat Fakültesi Dergisi, 47, 45-92.

Knowles, C. (1954). Caxton and his two French sources: the "Game and Playe of the Chesse" and the composite manuscripts of the two French translations of the "Ludus Scaccorum". The Modern Language Review, 49(4), 417-423.

Köymen, M. A. (1966). Alp Arslan zamanı Selçuklu saray teşkilâtı ve hayatı. Tarih Araştırmaları Dergisi, 4(6), 1-99.

Kutluer, İ. (2000). İbnü’t-Tayyib es-Serahsî. Türkiye Diyanet Vakfi İslâm Ansiklopedisi içinde. (21, s. 230-232), İstanbul: Türkiye Diyanet Vakfı Yayınları.

Maßmann, H. F. (1839). Geschichte des mittelalterlichen vorzugsweise des Deutschen schachspiels. Quedlinburg und Leipzig.

Macdonell, A. A. (1898). The origin and early history of chess. The Journal of the Royal Asiatic Society of Great Britain and Ireland, 117-141.

Makdisi, G. (2007). Íslam'ın klasik çă̆ında ve Hristiyan Batı'da beşerî bilimler. (H. T. Başoğlu, Çev.). İstanbul: Klasik Yayınları. (Orijinal çalışma basım tarihi 1990).

Mansfield, P. W. (2009). The chess master: living life on a chessboard \& letting god make all the moves. USA: Xlibris. 
Marozzi, J. (2006). Timurlenk İslam'ın kılıcı, cihan fatihi. (H. Kocaoluk, Çev.). İstanbul: Yap1 Kredi Yayınları. (Orijinal çalışma basım tarihi 2004).

Mevlânâ Celâleddin. (1992). Divân-ı kebir-5. (A. Gölpınarlı, Haz.). Eskişehir: Anadolu Üniversitesi Basımevi.

Muhammed b. Ali b. Süleyman er-Râvendi. (2020). Râhat-üs Sudûr ve Âyet-üs- Sürûr (3. baskı). (A. Ateş, Çev.). Ankara: Türk Tarih Kurumu Yayınları.

Murray, H. J. R. (1913). A history of chess. Oxford: Clarendon Press.

Musser, G. S. (2007). Los Libros de acedrex dados e tablas: historical, artistic and metaphysical dimensions of Alfonso X's Book of Games. (Yayımlanmamış doktora tezi). The University of Arizona, USA.

Nizam'ül-Mülk. (2021). Siyasetname (16. Bask1). (M. T. Ayar, Çev.). İstanbul: Türkiye İş Bankası Kültür Yayınları.

Oriesek, D. ve Schwarz J. O. (2008). Business wargaming: securing corporate value. USA: Gower.

Öz, M. (1997). Hâkim- Biemrillâh. Türkiye Diyanet Vakfi İslâm Ansiklopedisi içinde (15, s. 199-201). İstanbul: Türkiye Diyanet Vakfı Yayınları.

Özaydın, A. (2009). Sûlî, Ebû Bekir. Türkiye Diyanet Vakfi İslâm Ansiklopedisi içinde (37, s. 492-493). İstanbul: Türkiye Diyanet Vakfı Yayınları.

Özbek, S. (2001). Türkiye Selçuklularında kültürel hayat (Mevlânâ'nın Fihi Mâfih ve Mesnevi’sine göre). Afyon Kocatepe Üniversitesi Sosyal Bilimler Dergisi. 3(1), 41-58.

Öztunalı, O. (2017). Toledo Çevirmenler Okulu'nda gerçekleştirilen çalışmaların kültürlerarası yeri ve önemi. Dil Tarih Coğrafya Fakültesi Dergisi, 57(2), 1323-1339.

Pagnotti J. ve Russell III W. B. (2012). Exploring medieval European society with chess: an engaging activity for the world history classroom. The History Teacher, 46(1), 29-43.

Pankhurst, R. (1971). History and principles of Ethiopian chess. Journal of Ethiopian Studies, 9(2), 149-172.

Remus, H. (2003). The origin of chess and the silk road. Silk Road Journal, 1(1), 6-9.

Schulte, M. (2017). Board games of the Vikings - from hnefatafl to chess. Maal og Minne, 2, $1-42$.

Sivrioğlu, U. T. (2013). İslâm kaynaklarına göre Nuşirevân-I Âdil. History Studies, 5(5), 225 252. 
Tamerlane chess: recreating fourteenth-century chess variant (30 Ocak 2018). Indiana University Bloomington. https://iaunrc.indiana.edu/news-events/news/tamerlanechess.html

Taneri, A. (1967). Büyük Selçuklu İmparatorluğu'nda vezîrlik. Tarih Araştırmaları Dergisi, 5(8), 75-186.

The spread of chess. Vivid Maps. https://vividmaps.com/the-spread-of-chess/

Turan, O. (1958). Türkiye Selçukluları hakkında resmî vesikalar metin tercüme ve araştırmalar. Ankara: Türk Tarih Kurumu Yayınları.

Turan, O. (2005). Selçuklular tarihi ve Türk-İslâm medeniyeti (8. bask1). İstanbul: Ötüken Yayınlar1.

Utas, B. ve Dabirsiaqi M. (1991). Chess. Encyclopcedia Iranica içinde. (s. 393-397). https://www.iranicaonline.org/articles/chess-a-board-game

Ünver, İ. (2001). Sulı, Suli, Sula, Sule, Süle ve Süli fakih rivayetleri üzerine. Türkoloji Dergisi, 14(1), 15-20.

Wilson, F. (1981). A picture history of chess. New York: Dover Publications.

Yalom, M. (2005). Birth of the chess queen. New York: HarperCollins e-books.

Yıldırım, T. (2016). Abbasîler'de sportif faaliyetler ve eğlence kültürü. Fırat Üniversitesi Sosyal Bilimler Dergisi, 26(2), 351-367.

Yıldız, S. N. (2018). Sultan için bir nedîm: Râvendî ve Anadolu Selçukluları. (A.S. Aykut, Çev.). Anadolu Selçukluları Ortaçă̆ Ortadoğusu ’nda Saray ve Toplum içinde (s. 7994). İstanbul: Yapı Kredi Yayınları.

Yılmaz, M. (2018). Bizans kaynaklarına göre Ankara savaşı. Uluslararası Sosyal Araştırmalar Dergisi, 11(60), 460-481.

Yüksel, M. Ş. (2004). Arap kaynaklarında Timur. Bilig, 31, 85-126. 